\title{
Quantitative Changes in the Synaptic Vesicle Proteins Synapsin I and p38 and the Astrocyte-Specific Protein Glial Fibrillary Acidic Protein Are Associated with Chemical-Induced Injury to the Rat Central Nervous System
}

\author{
Thomas O. Brock ${ }^{a}$ and James P. O'Callaghan \\ Neurotoxicology Division, Health Effects Research Laboratory, United States Environmental Protection Agency, Research \\ Triangle Park, North Carolina 27711
}

\begin{abstract}
Measurements of neuron-specific and glia-specific proteins were used to characterize chemical-induced injury to the rat CNS. Trimethyltin (TMT), a neurotoxicant that preferentially damages neurons in limbic structures, was employed to produce consistent, time-dependent, dose-related, cell type-specific alterations in CNS morphology. Brain weights and histology were used to verify the cytopathological effects of TMT. Accompanying changes in 2 synaptic vesicleassociated proteins, synapsin I and p38, and the astrocyteassociated protein, glial fibrillary acidic protein (GFAP), were measured by radioimmunoassay (RIA). Immunohistochemistry of GFAP and incorporation of ${ }^{3} \mathrm{H}$-thymidine into GFAPpositive astrocytes also were used to characterize astrocytic responses to TMT-induced injury. Finally, quantitative 2-dimensional PAGE was employed to detect additional proteins affected by TMT. Acute administration of TMT caused large dose- and time-dependent decreases in synapsin I and p38 in hippocampus; the same proteins were largely unaffected in a nonlimbic structure, the frontal cortex. Twelve weeks after dosing, the concentrations of synapsin $I$ and p38 and, to a lesser extent, the absolute amount of these proteins in hippocampus had returned to near control values, findings that are suggestive of reactive synaptogenesis. TMT caused large dose- and time-dependent increases in GFAP that were not confined to hippocampus. Twelve weeks after dosing, the amounts of GFAP in hippocampus and frontal cortex had returned to near control values, findings indicative of a transient astrocytic response to brain injury. Immunohistochemistry of GFAP revealed widespread astrocytic reactivity as a consequence of exposure to TMT, a response that resulted in part from the proliferation of
\end{abstract}

\footnotetext{
Received Feb. 21, 1986; revised Sept. 22, 1986; accepted Sept. 25, 1986.

The authors wish to thank Mr. Michael E. Viana for excellent technical assistance, Ms. Donna Jenkins for preparation of the brain sections, Ms. Julia Davis for photographic assistance, and Drs. Melvin E. Billingsley, Michael D. Browning, Linda J. Burdette, Paul Greengard, Reinhard Jahn, and Diane B. Miller for useful discussions. T.O.B. received support from a National Research Council Research Assistantship. This paper has been reviewed by the Health Effects Research Laboratory, U.S. Environmental Protection Agency, and approved for publication.

Correspondence should be addressed to James P. O'Callaghan, Ph.D., Neurotoxicology Division (MD-74B), U.S. Environmental Protection Agency, Research Triangle Park, NC 27711.

a Present address: Department of Child Development, Biological Sciences Research Center, University of North Carolina, School of Medicine, Building $220 \mathrm{H}$ Chapel Hill, NC 27514

0270-6474/87/040931-12\$02.00/0
}

astrocytes. Additional neurotypic proteins altered by TMTinduced injury included one of the neurofilament (NF) triplet proteins (p68) and a protein with the electrophoretic characteristics of neuron-specific enolase (NSE). The data indicate that measurements of neurotypic and gliotypic proteins may be used to characterize the temporal and regional patterns of neuronal and glial responses to injury.

Chemical-induced injury to the mammalian CNS is often manifested by alterations in the cytoarchitecture of specific neuroanatomical regions. Within the affected area, the response to chemical insult may encompass several types of neurons and glia (Price and Griffin, 1980; Spencer and Schaumberg, 1980). Because proteins that distinguish the diverse cell types comprising the mammalian nervous system have been described (Raff et al., 1979; Schachner, 1982; Milner and Sutcliffe, 1983; De Blas et al., 1984; Nestler and Greengard, 1984; Nestler et al., 1984), we proposed that measurements of these nervous system-specific proteins could be used to detect and characterize the cellular responses to chemical-induced injury (O'Callaghan and Miller, 1983). In support of this hypothesis, we have demonstrated that the cytopathological changes caused by several known neurotoxicants are accompanied by quantitative changes in proteins associated with the affected cell types (O'Callaghan et al., 1983; Miller and O'Callaghan, 1984; O'Callaghan and Miller, 1984, 1985, 1986).

One neurotoxic chemical employed in our previous studies was trimethyltin (TMT), an organometallic compound that preferentially destroys limbic system neurons (Brown et al., 1979; Bouldin et al., 1981; Chang and Dyer, 1983). By using TMT as a denervation tool to alter the morphology of a limbic structure, the hippocampus, we were able to demonstrate accompanying changes in neuron-specific phosphoproteins ( $\mathrm{O}^{\prime}$ Callaghan and Miller, 1984). On the hasis of both radioenzymatic assays and radioimmunoassays (RIAs), we found that acute administration of TMT to the rat resulted in large, dose-related decreases in hippocampal synapsin I, a synapse-specific, synaptic vesicleassociated phosphoprotein (De Camilli et al., 1983a, b; Huttner et al., 1983; Navone et al., 1984; Nestler et al., 1984). Consistent with the region-selective effects of TMT, decrements in synapsin I were not observed in the frontal cortex. These data suggested that measurements of nervous system-specific proteins could be used to characterize and quantify region-selective and cell typespecific responses to CNS injury.

The objective of the present study was to characterize the 
Table 1. Time course of the effects of TMT on weights of hippocampus and frontal cortex

\begin{tabular}{rlll} 
Day & Treatment $^{a}$ & $\begin{array}{l}\text { Hemihippocampus } \\
(\mathrm{gm})^{b}\end{array}$ & $\begin{array}{l}\text { Hemifrontal cortex } \\
(\mathrm{gm})^{b}\end{array}$ \\
\hline 7 & Saline & $0.056 \pm 0.004$ & $0.054 \pm 0.002$ \\
7 & TMT & $0.050 \pm 0.001$ & $0.055 \pm 0.002$ \\
21 & Saline & $0.055 \pm 0.002$ & $0.054 \pm 0.003$ \\
21 & TMT & $0.044 \pm 0.001^{* *}$ & $0.055 \pm 0.003$ \\
35 & Saline & $0.055 \pm 0.002$ & $0.054 \pm 0.003$ \\
35 & TMT & $0.036 \pm 0.002^{* *}$ & $0.054 \pm 0.002$ \\
84 & Saline & $0.058 \pm 0.002$ & $0.058 \pm 0.002$ \\
84 & TMT & $0.042 \pm 0.004^{*}$ & $0.056 \pm 0.003$
\end{tabular}

${ }^{a}$ Subjects were treated with saline $(0.9 \%)$ or TMT $(8.0 \mathrm{mg} / \mathrm{kg})$.

${ }^{b}$ Each value $(n=5)$ represents the mean weight \pm SEM.

* Significantly different from corresponding saline control, $p<0.01$.

** Significantly different from corresponding saline control, $p<0.001$.

time- and dose-dependent changes in both neuron-specific (neurotypic) and glia-specific (gliotypic) proteins as a consequence of chemical-induced injury of the CNS. Following the administration of TMT, the synaptic protein synapsin I and another synaptic vesicle-localized protein, p38 (Jahn et al., 1985; Wiedenmann and Franke, 1985), as well as the astroglia-localized protein, glial fibrillary acidic protein (GFAP) (Bignami et al., 1972, 1980; Eng, 1980, 1985), were quantified by RIA. Immunohistochemistry of GFAP was employed to evaluate patterns of astrocytic response to injury. Finally, quantitative 2-dimensional PAGE was used to identify additional neurotypic and gliotypic proteins affected as a consequence of the administration of TMT. Our results demonstrated that measurements of neurotypic and gliotypic proteins could be used to characterize the temporal and regional patterns of neuronal and glial response to chemical-induced injury of the CNS.

A preliminary report of portions of this investigation has previously appeared (Viana et al., 1985).

\section{Materials and Methods}

Materials. Bolton-Hunter reagent, ${ }^{125} \mathrm{I}$-protein $\mathrm{A}(2-10 \mu \mathrm{Ci} / \mu \mathrm{g} ; 1 \mathrm{Ci}=$ $37 \mathrm{GBq})$ and ${ }^{3} \mathrm{H}$-thymidine $(6.7 \mathrm{Ci} / \mathrm{mm} ; 1 \mathrm{Ci}=37 \mathrm{GBq})$ were purchased from New England Nuclear (Boston, MA). Synapsin I and corresponding antisera were the gifts of Drs. Jesse Chan and Eva Perdahl (Rockefeller University). Monoclonal antibodies to p38 (c7.1, c7.2, and c7.3) were the gift of Dr. Reinhard Jahn (Rockefeller University). Antiserum to GFAP, GFAP immunohistochemistry kits, and rabbit anti-mouse IgG were from Dako (Santa Barbara, CA). Monoclonal antineurofilament protein (p68) was from Boehringer Mannheim Biochemicals (Indianapolis, IN). Nitrocellulose paper $(0.2 \mu \mathrm{M}$ pore size, of German manufacture) was purchased from Schleicher and Schuell (Keene, NH). Other reagents and materials used in the RIAs were from the reported sources (Goelz et al., 1981; Nairn et al., 1982; Jahn et al., 1984). All reagents for 2-dimensional PAGE were purchased from Bio-Rad Laboratories (Richmond, CA), with the following exceptions: Tris and dithiothreitol were from Calbiochem (San Diego, CA), Nonidet P-40 was obtained from Particle Data Labs (Elmhurst, IL), and ampholines, $\mathrm{pH}$ 3.5-10, were from LKB (Gaithersburg, MD). Ovalbumin, BSA, and molecular weight standards were purchased from Sigma Chemical Company (St. Louis, MO). Nuclear track emulsion (NTB-2) and XRP x-ray film were obtained from Kodak (Rochester, NY). TMT hydroxide was purchased from ICN Pharmaceuticals (Plainview, NY). All other reagents were of the highcst analytical grade and wcre obtaincd from various commercial sources.

Subjects. Male Long-Evans rats (200-250 gm), purchased from Charles River Breeding Laboratories (Wilmington, MA), were housed individually in a temperature $\left(22^{\circ} \mathrm{C} \pm 2\right)$ - and humidity $(50 \pm 10 \%)$-controlled colony room maintained on a $12 \mathrm{hr}$ light: $12 \mathrm{hr}$ dark cycle beginning at 0600 . Food (Purina Rat $\mathrm{Chow}$ ) and water were continuously available. The animals were administered TMT or its vehicle ( $0.9 \%$ saline) by injection into a lateral tail vein; dosages of 'TMT are expressed as the free base and were administered in a volume of $1.0 \mathrm{ml} / \mathrm{kg}$ body weight. Dose-effect determinations $(0.0-9.0 \mathrm{mg} / \mathrm{kg}$ TMT) were made $21 \mathrm{~d}$ postdosing. Time-effect determinations were made after the administration of saline or $8.0 \mathrm{mg} / \mathrm{kg}$ TMT. All subjects were killed by decapitation.

Brain dissection and tissue preparation. Immediately after decapitation, whole brains were removed from the skull and then bisected in the midsagittal plane. The left hemibrains were prepared for histological examination (see below) and the right hemibrains were prepared for biochemical measurements according to the following procedures: the hippocampus was removed by free-hand dissection and the frontal cortex was obtained by coronal section (free-hand) at the level of the anterior commissure (bregma, $2.7 \mathrm{~mm}$; see Paxinos and Watson, 1982) Care was taken not to include olfactory nuclei or olfactory cortex with samples of frontal cortex. The dissected brain regions were weighed, homogenized by sonification (Kontes cell disrupter) in 10 volumes of hot $\left(90-95^{\circ} \mathrm{C}\right)$ SDS and then frozen at $-70^{\circ} \mathrm{C}$ for subsequent analysis by RIA and 2-dimensional PAGE (see below). In one of the experiments, subfields of dorsal hippocampus were dissected, as previously described (O'Callaghan and Miller, 1984). In brief, five 700- $\mu \mathrm{M}$-thick serial transverse sections were prepared with a McIlwain tissue chopper (Brinkman Instruments, Westbury, NY). With the aid of a dissecting microscope, individual slices were divided into areas approximating $\mathrm{CA} 1, \mathrm{CA} 3$, and fascia dentata using a modification (O'Callaghan and Miller, 1984, and see legend to Table 2) of the procedure of Danscher et al. (1976). The samples from a given region were then pooled, sonified in $75 \mu \mathrm{l}$ of hot SDS, and stored at $-70^{\circ} \mathrm{C}$ before RIA

Histology. The left hemibrains were immersion-fixed in $10 \%$ neutralbuffered Formalin immediately after removal from the skull. The tissue was embedded in paraffin and sectioned in the sagittal plane, beginning at the midline. Two sequential sections were cut at thicknesses of 10 and $6 \mu \mathrm{M}$ every $100 \mu \mathrm{M}$; the $10 \mu \mathrm{M}$ sections were stained with cresyl violet and the $6 \mu \mathrm{M}$ sections were prepared for immunohistochemistry and autoradiography (see below). With the aid of a $1 \mu \mathrm{M}$ ocular grid, estimations of hippocampal pyramidal cell loss were made by counting the number of cells (CA1-CA4) with an intact nucleus and a prominent nucleolus. Counts were obtained every third section ( $300 \mu \mathrm{M}$ distance) throughout the hippocampal formation. The nomenclature of Lorente de Nó (1934) was used to describe anatomical subdivisions of the hippocampal formation.

RIA of synapsin I. Synapsin I was measured by detergent-based RIA according to the procedure of Goelz et al. (1981). Samples were normalized in $1 \%$ SDS to a protein concentration of $5 \mathrm{mg} / \mathrm{ml}$ before undergoing 1:50 dilution in RIA buffer (Goelz et al., 1981). Samples, including standards, were assayed in quadruplicate using the microtiter plate system as described by Nairn et al. (1982).

$R I A$ of $p 38$. Quantification of $\mathrm{p} 38$ was achieved by a modification of the dot-immunobinding procedure of Jahn et al. (1984). In our procedure, samples were applied to the nitrocellulose sheets, using a slot-blot apparatus (Minifold II; Schleicher and Schuell) as a template. This modification resulted in faster sample application, greater reproducibility, and a greater sample capacity per $\mathrm{cm}^{2}$ of nitrocellulose than the original procedure (see Jahn et al., 1984). Samples containing $8.75 \mu \mathrm{g}$ protein in $20 \mu \mathrm{l}$ sample buffer were loaded into each well. Incubation of the nitrocellulose sheets with a mixture of monoclonal antibodies against $\mathrm{p} 38$ (1:2000 each) was followed by washing in Tris-buffered saline and additional incubation in blocking solution for $30 \mathrm{~min}$ (see Jahn et al., 1984). This step was followed by incubation in rabbit antimouse IgG (1:500) for $1 \mathrm{hr}$, with subsequent washing and blocking before incubation in ${ }^{125} \mathrm{I}$-protein $\mathrm{A}$. The specificity and linearity of the p38 assay have been described (Jahn et al., 1984, 1985).

$R I A$ of GFAP. GFAP was assayed by the dot-immunobinding procedure of Jahn et al. (1984) as previously described (O'Callaghan and Miller, 1985), with the exception that the technique for sample application was modified as described above for $\mathrm{p} 38$. Each sample contained $3.75 \mu \mathrm{g}$ protein in $20 \mu \mathrm{l}$ sample buffer. Antiserum to GFAP was used at a dilution of 1:500; the specificity of the GFAP antiserum and the lincarity of the assay have been described (O'Callaghan and Miller, 1985).

Expression of RIA data. For assays of synapsin I, p38, and GFAP, standard curves were constructed from dilutions of a single control sample. By comparing the immunoreactivity of each sample (saline and 

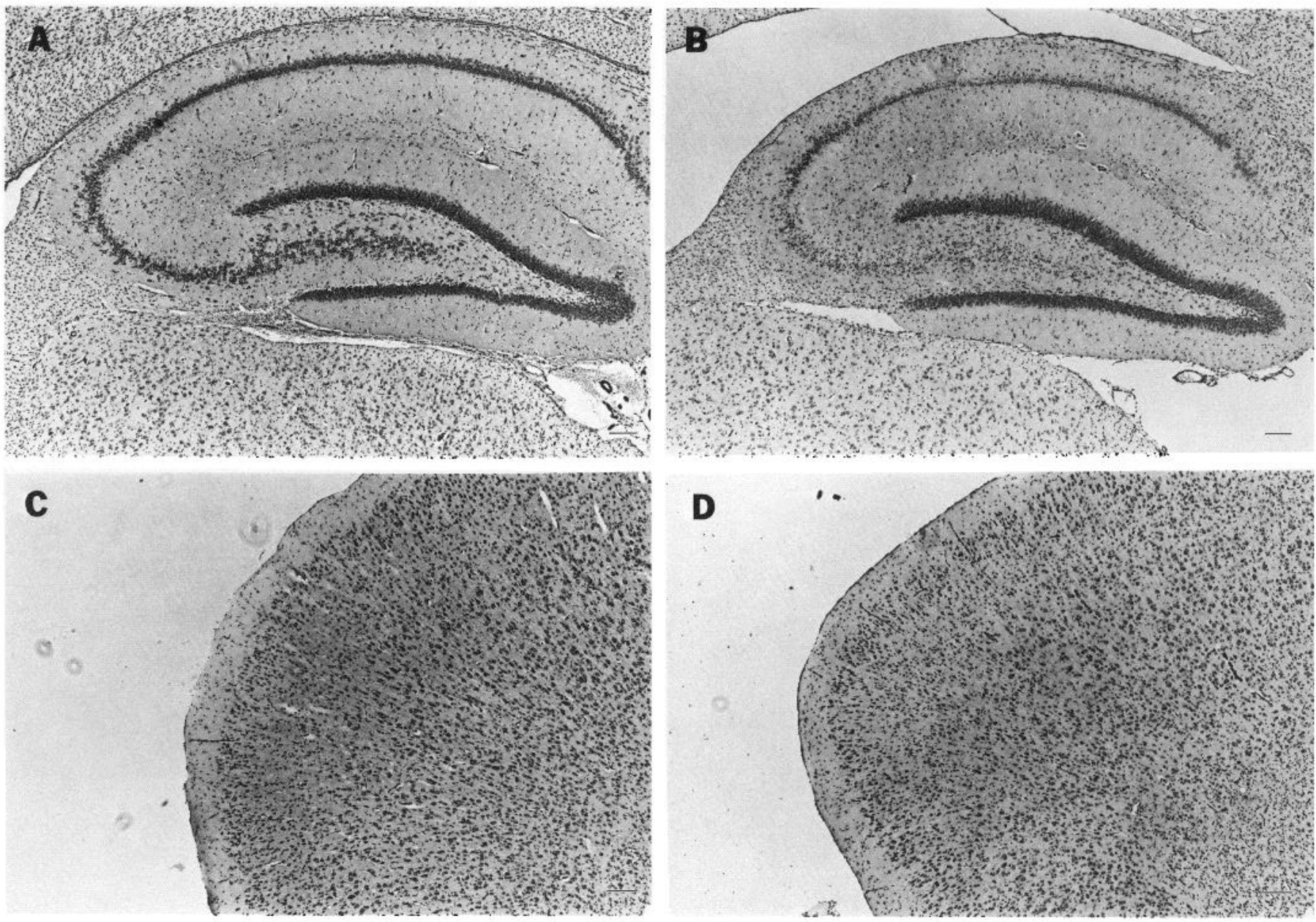

Figure 1. Morphology of dorsal hippocampus $(A, B)$ and frontal cortex $(C, D) 21 \mathrm{~d}$ after the acute administration of saline, $0.9 \%(A, C)$ or TMT, $8.0 \mathrm{mg} / \mathrm{kg}(B, D)$. Bars, $100 \mu \mathrm{M}$. Note extensive loss of pyramidal cells in CA3-CA4 due to TMT $(B)$. In contrast, neuronal loss was not obvious in frontal cortex of TMT-treated subjects $(D)$

TMT) with that of the sample used to construct the standard curve, the relative specific activity (RSA) of each sample was obtained (e.g., see O'Callaghan and Miller, 1984, 1985). The RSA of an individual sample (saline and TMT) was then multiplied by a constant that resulted in a mean RSA of $1.0(100 \%)$ for the saline groups specified in the legends to Figures 3-6 and Table 2. Data are expressed on the basis of both the total (per tissue) and concentration (per milligram tissue protein). RSA values for total (synapsin I, p38, or GFAP) reflect the amount of the protein assayed per hippocampus or frontal cortex, whereas RSA values for concentration (synapsin I, p38, or GFAP) reflect the amount of the protein assayed per milligram of hippocampus or frontal cortex protein. Thus, changes in the RSA total would be indicative of changes in the absolute amount of a given protein, whereas changes in the RSA concentration would indicate alterations in the relative abundance of a given protein.

Protein assay. Total protein was determined by the method of Lowry et al. (1951) using BSA as the standard.

Immunohistochemistry and microautoradiography. Sections (6 $\mu \mathrm{M})$ obtained from the left hemibrain were deparaffinized, incubated in $0.1 \%$ trypsin for $15 \mathrm{~min}$, and immunostained for GFAP according to the indirect immunoperoxidase method of Sternberger et al. (1970); the chromogen was aminoethylcarbazole. In some cases slides were counterstained with Mayer's hematoxylin. The anti-GFAP used for immunohistochemistry was the same as that employed in the RIA. Control slides, prepared by omitting the primary antiserum or by using nonimmune rabbit serum, demonstrated that the staining for GFAP was specific.

For autoradiography, subjects that had received saline or TMT ( 8 $\mathrm{mg} / \mathrm{kg}) 1,2,3,4$, or $5 \mathrm{~d}$ earlier were given an intraventricular injection of ${ }^{3} \mathrm{H}$-thymidine ( $20 \mu \mathrm{Ci}$ in $20 \mu \mathrm{l}$ of water) as described (Billingsley et al., 1982) and killed $1 \mathrm{hr}$ later. Brains were removed and processed for immunohistochemistry of GFAP, as described above. The slides then were dipped in NTB-2 emulsion diluted $1: 1$ with $0.1 \%$ SDS and developed 1 week later by the method of Kopriwa and Leblond (1962). The number of GFAP-positive cells (astrocytes), and the number of GFAP-positive cells with reduced silver halide grains over their nuclei were determined in the CA3c-CA4 regions of hippocampus. A cell was counted as an astroycte if it had an intact nucleus with positive staining for GFAP in the perikaryon or the cytoplasmic processes. Counts were obtained from sections taken every $300 \mu \mathrm{M}$ throughout the extent of the hippocampal formation.

Two-dimensional gel electrophoresis and densitometry. Samples of hippocampus and frontal cortex ( $150 \mu \mathrm{g}$ homogenate protein) were subjected to 2-dimensional PAGE according to the procedure of O'Farrell (1975), except that the concentration of acrylamide in the second dimension was $10 \%$. After electrophoresis, gels were stained with Coomassie blue R-250 and dried between sheets of dialysis membrane using heat and reduced pressure. To identify the spots corresponding to GFAP and NF p68, samples were subjected to 2-dimensional PAGE and were transferred electrophoretically (Towbin et al., 1979; Burnette, 1981) onto sheets of nitrocellulose. One sheet was assayed for GFAP as described above and another sheet was assayed for neurofilament (NF) p68 according to the double-antibody procedure described above for p38. Using autoradiography to localize radioactivity bound to each transfer, it was revealed that the antibodies to GFAP and NF p68 were localized at positions corresponding to the electrophoretic mobility of GFAP and NF p68, respectively (data not shown). Serum albumin, actin, and $\alpha$ - and $\beta$-tubulin were identified on the basis of comigration 


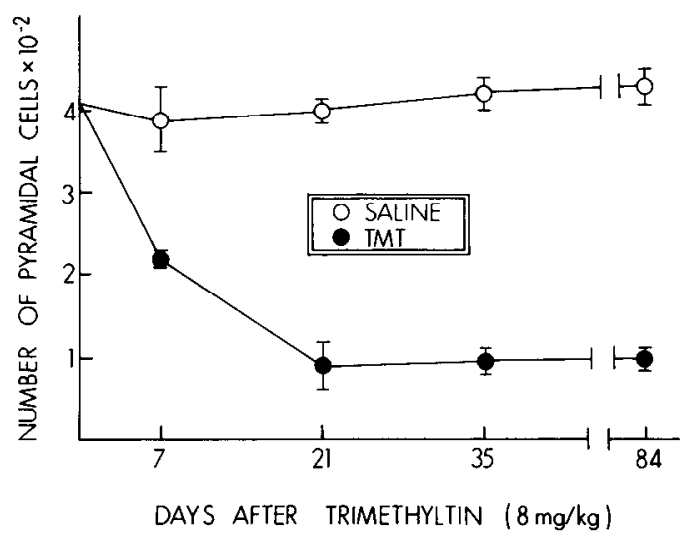

Figure 2. Time course of hippocampal pyramidal cell loss following the acute administration of TMT $(8.0 \mathrm{mg} / \mathrm{kg})$. Estimations of hippocampal pyramidal cell number were made as described in Materials and Methods. Each value represents the mean $\pm \operatorname{SEM}(n=5)$. The mean value for the combined cell counts obtained from saline-treated subjects $(n=20)$ is presented where lines are drawn to the ordinate.

with the pure proteins (see Brock and Mcllwain, 1985). To quantify specific proteins, the stained gels were scanned with a computer-assisted, television-based image analyzer (Darwin Instruments, Winston-Salem, NC; see Telewski et al., 1983, for a description). The integrated optical density (IOD) for selected proteins was determined after subtraction of background values. The IOD for each protein spot was divided by the IOD of ovalbumin that had been added to each sample before electrophoresis to control for gel-to-gel differences with respect to the degree of staining or the amount of protein that entered each gel (Sinicropi and McIlwain, 1983). The IOD values for all proteins subjected to densitometry were shown to be linearly related to the amounts of protein applied to the gels over the range of densities observed for each protein.

Statistical analysis. The Statistical Analysis System (SAS; 1982) was used for data analyses. Treatment effects were analyzed by the $t$ statistic or by analysis of variance (ANOVA). Duncan's Multiple Range Test was used to make group comparisons following a significant ANOVA. When group variances were unequal, comparisons were made by $T$, an approximate $t$ statistic with Satterthwaite's approximation for the degrees of freedom (1946).

\section{Results}

Brain weights. Acute administration of TMT caused dose- and time-dependent decreases in hippocampal weight without affecting the weight of frontal cortex. Time-course data for the effects of $8.0 \mathrm{mg} / \mathrm{kg}$ of TMT are shown in Table 1 . Twenty-one days after administration of TMT, hippocampal weight was reduced by $20 \%$, an effect that was still evident 9 weeks later.

Histology. TMT $(8 \mathrm{mg} / \mathrm{kg}$ ) caused the characteristic destruction of hippocampal pyramidal cells with sparing of granule neurons (Fig. 1). Areas CA3-CA4 appeared to be the most affected; however, neuron loss was noted throughout the pyramidal cell layer in all sections examined. Consistent with our previous findings (O'Callaghan and Miller, 1984), the acute administration of TMT was not associated with qualitative changes in the morphology of the frontal cortex, a nonlimbic region (Fig. 1). Time-course data for the effects of TMT on pyramidal cell number are presented in Figure 2. Twenty-one days after the administration of TMT, the number of pyramidal cell neurons had declined to $25 \%$ of control values; no further reductions in pyramidal cell number were observed by $84 \mathrm{~d}$ postdosing.

RIA of synapsin I and 38 in hippocampus and frontal cortex. The changes in hippocampal morphology $21 \mathrm{~d}$ after administration of TMT were associated with dose-related decreases in the synaptic vesicle-associated proteins synapsin I and p38 (Fig.
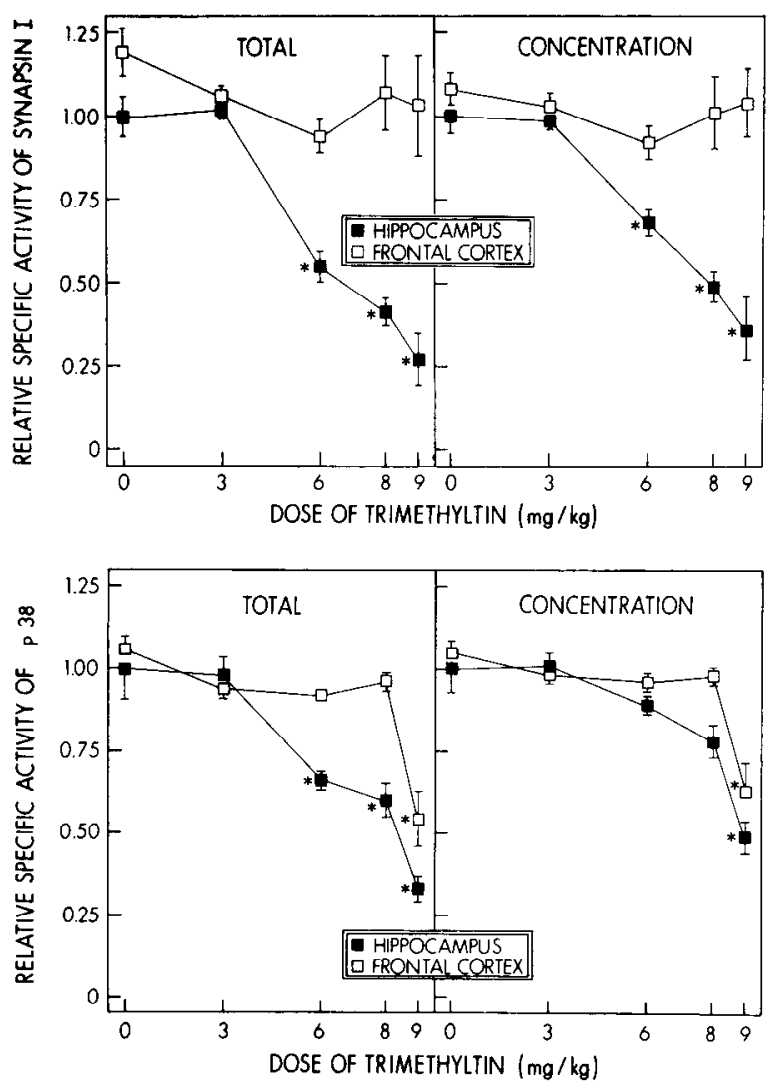

Figure 3. Effects of TMT on synapsin I (upper panels) and p38 (lower panels) in hippocampus and frontal cortex. Subjects were killed $21 \mathrm{~d}$ after treatinent. Each value $(n=4-5)$ represents the mean RSA \pm SEM expressed on a total (per structure) or concentration (per mg protein) basis; where vertical lines are not shown, the SEM is smaller than the data point. Values obtained for hippocampus-saline $(0 \mathrm{mg} / \mathrm{kg})$ were used to calculate a mean RSA $=1.0$; see Materials and Methods for additional details. *Significantly different from saline control, $p<0.01$.

3). These effects of TMT were evident whether the data were expressed on a total (per hippocampus) or concentration (per milligram hippocampus protein) basis. In order to determine whether values for synapsin I and p38 would reflect the regional specificity of TMT-induced injury, the amounts of these proteins in frontal cortex were determined. In agreement with our previous observations (O'Callaghan and Miller, 1984), TMT did not affect values for synapsin $I$ in frontal cortex. At the highest dosage tested, however, TMT caused large (40-45\%) decrements in $\mathrm{p} 38$ (total and concentration).

The time course for the effects of TMT $(8 \mathrm{mg} / \mathrm{kg})$ on synapsin $\mathrm{I}$ and $\mathrm{p} 38$ is shown in Figure 4. No significant changes in hippocampal synapsin I and p38 were observed $1,2,3$, or $5 \mathrm{~d}$ following exposure to TMT. Seven days after administration of TMT, values (total and concentration) for hippocampal synapsin $I$ and p38 began to decline; maximal reductions were reached $35 \mathrm{~d}$ after dosing. Values for total hippocampal synapsin I and p38 increased slightly between 35 and 84 d postdosing but still remained well below corresponding control values. During this period, the concentration of synapsin I and p38 returned to near control values. The RSA (total and concentration) for synapsin I and p38 in frontal cortex did not differ significantly within the 12 week time course of the experiment.

RIA of GFAP in hippocampus and frontal cortex. In contrast to the results obtained for synapsin I and p38, there were large 

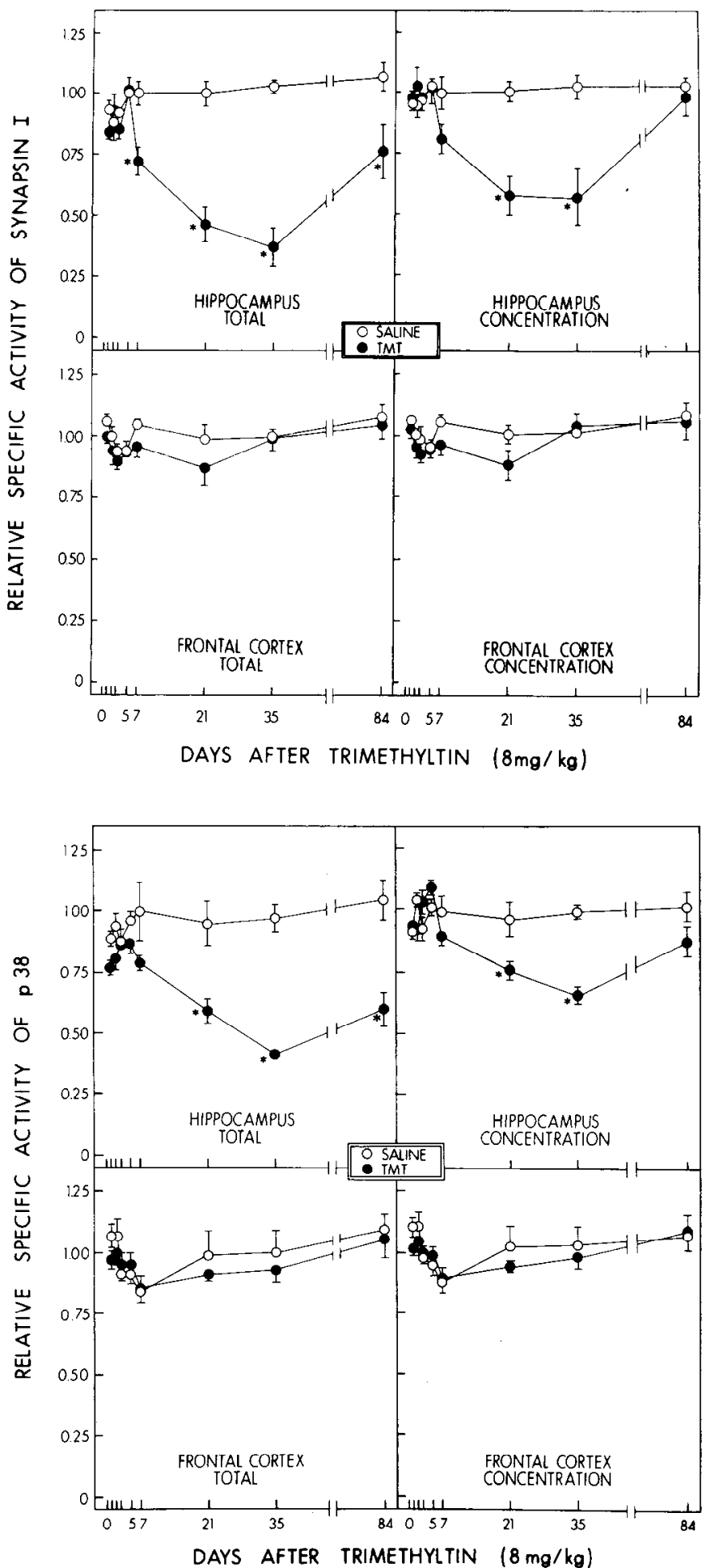

Figure 4. Time course of the effects of $8.0 \mathrm{mg} / \mathrm{kg}$ of TMT on synapsin I (upper panels) and p38 (lower panels) in hippocampus and frontal cortex. Each value $(n=5)$ represents the mean RSA \pm SEM expressed on a total (per structure) or concentration (per mg protein) basis; where vertical lines are not shown, the SEM is smaller than the data point. Values obtained for hippocampus-saline $(7 \mathrm{~d})$ were used to calculate a mean RSA $=.1 .0$; see Materials and Methods for additional details. *Significantly different from saline control, $p<0.01$.

dose-related increases in GFAP (total and concentration) associated with TMT-induced injury that were not restricted to the hippocampus (Fig. 5). Twenty-one days after administration

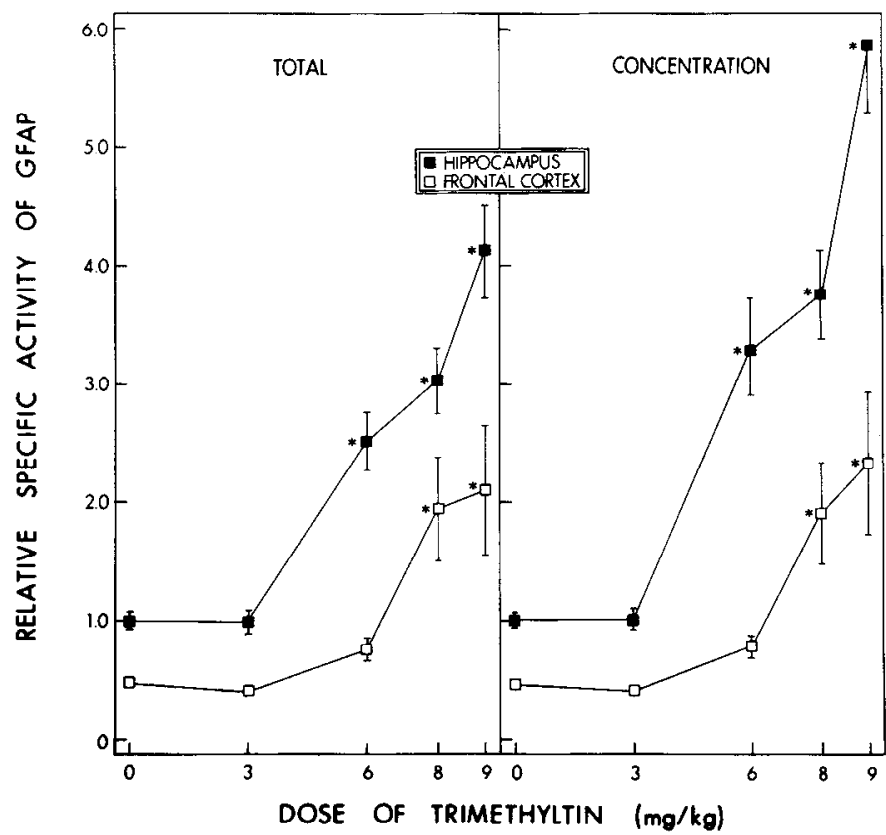

Figure 5. Effects of TMT on GFAP in hippocampus and frontal cortex. Subjects were killed $21 \mathrm{~d}$ after treatment. Each value $(n=4-5)$ represents the mean RSA \pm SEM expressed on a total (per structure) or concentration (per mg protein) basis; where vertical lines are not shown, the SEM is smaller than the data point. Values obtained for hippocampussaline $(0 \mathrm{mg} / \mathrm{kg})$ were used to calculate a mean $\mathrm{RSA}=1.0$. In the saline $(0 \mathrm{mg} / \mathrm{kg}) \mathrm{groups}$, note that the amount of GFAP in frontal cortex is approximately half the amount of GFAP in hippocampus. See Materials and Methods for additional details. *Significantly different from saline control, $p<0.01$.

of TMT, values for GFAP in the hippocampus were increased by as much as 300 and $500 \%$ when expressed on a total and concentration basis, respectively. In frontal cortex, the corresponding increases in GFAP were not as large in magnitude as those in hippocampus; however, because control $(0 \mathrm{mg} / \mathrm{kg})$ values for GFAP in frontal cortex were roughly half those of hippocampus, the increases in frontal cortex GFAP, expressed as a percentage of control $(0 \mathrm{mg} / \mathrm{kg}$; frontal cortex), were nearly comparable to the corresponding increases observed in hippocampus.

The time course of the effects of TMT $(8.0 \mathrm{mg} / \mathrm{kg})$ on GFAP is shown in Figure 6. The temporal relationship of the TMTinduced increases in GFAP (hippocampus and frontal cortex) was similar to that of the decreases observed for synapsin I and p38 (hippocampus): significant increases were not observed until $7 \mathrm{~d}$ postdosing, maximal effects were observed at day 35 , and values had returned to near control levels by day 84 .

RIA of $p 38$ and GFAP in regions of dorsal hippocampus. Slices of hippocampus were dissected into areas roughly approximating the major neuronal subfields to determine the intrahippocampal distribution of $\mathrm{p} 38$ and GFAP and the extent to which each protein was altered by TMT in a given area (Table 2). The values for $\mathrm{p} 38$ were uniformly distributed among hippocampal subfields, a finding consistent with our previous observation that the concentration of synapsin I did not vary among regions of the hippocampus (O'Callaghan and Miller, 1984). Furthermore, as with its effects on synapsin I (O'Callaghan and Miller, 1984), TMT caused decreases in the content (total and concentration) of p38 in all regions of the hippocampal formation. 


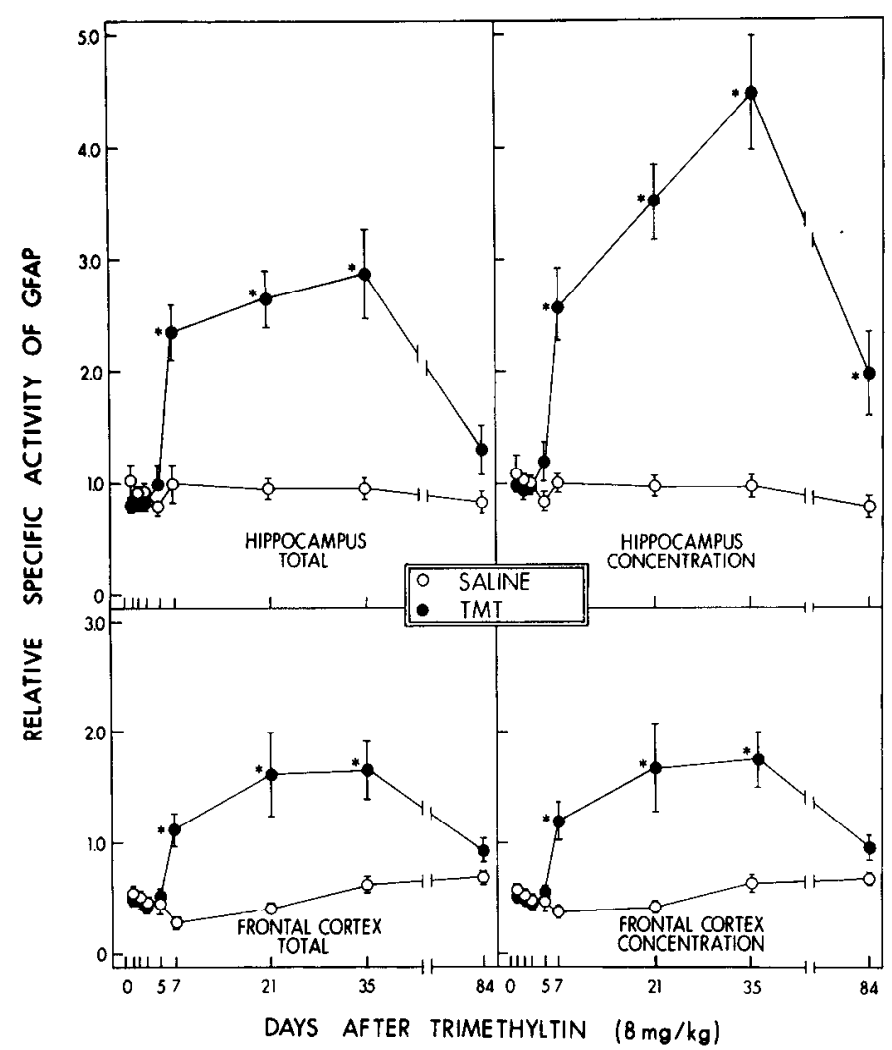

Figure 6. Time course of the effects of $8.0 \mathrm{mg} / \mathrm{kg}$ of TMT on GFAP in hippocampus and frontal cortex. Each value $(n=5)$ represents the mean RSA \pm SEM expressed on a total (per structure) or concentration (per $\mathrm{mg}$ protein) basis. Values obtained for hippocampus-saline $(7 \mathrm{~d})$ were used to calculate a mean $\mathrm{RSA}=1.0$. In the saline $(0 \mathrm{mg} / \mathrm{kg})$ groups, note that the amount of GFAP in frontal cortex is approximately half the amount of GFAP in hippocampus. See Materials and Methods for additional details. *Significantly different from saline control, $p<0.01$.

Unlike the case with synapsin I and p38, the distribution of GFAP within the hippocampus was uneven. Values for GFAP in fascia dentata (which includes $\mathrm{CA} 3 \mathrm{c}, \mathrm{CA} 4$, and fascia dentata; see Table 2) were nearly double those of area CAl and were more than 8 times greater than those of CA3. The effect of TMT on GFAP also varied with respect to hippocampal areas; for example, 13-, 15-, and 67-fold increases in concentration were observed in fascia dentata, CA1, and CA3, respectively.

Immunohistochemistry of GFAP. The increased concentration of GFAP in all regions of the hippocampus and in frontal cortex was suggestive of a widespread astrocytic response to TMT-induced injury. To explore this possibility, we used the antisera employed in the RIA to localize GFAP by immunocytochemistry. Representative light micrographs of tissue obtained from saline- and TMT-treated rats are shown in Figure 7. Although several investigators (Bignami and Dahl, 1976; Eng and De Armond, 1982; Barrett et al., 1984; Mathewson and Berry, 1985) have reported that GFAP immunoreactivity is weak throughout the CNS of animals that have not undergone nervous system trauma, we found that GFAP immunoreactivity delineated stellate-shaped astrocytes in hippocampus (Fig. 7, $A$, $C)$ and frontal cortex (Fig. 7E) of control subjects. GFAP immunoreactivity was distributed throughout all areas of the hippocampal formation (Fig. 7A) and was intense in the astrocytic processes, less so in the perikaryon, and absent in nuclei (Fig. 7 C). Twenty-one days after exposure to TMT $(8.0 \mathrm{mg} / \mathrm{kg})$, GFAP immunoreactivity had increased in all cell layers of the hippocampus (Fig. $7 B$ ); astrocytes proximal to neurons in CAl, CA3, and CA4 appeared to be most intensely immunoreactive. In comparison to immunoreactive astrocytes present in hippocampus from saline-treated rats (Fig. $7 C$ ), those present in hippocampus from TMT-treated rats were characterized by markedly hypertrophied perikarya and processes (Fig. $7 D$ ). Increased immunoreactivity associated with swollen astrocytes was also seen in frontal cortex 3 weeks after administration of TMT (Fig. $7 F$ ). By day 84 after exposure to TMT, astrocytic reactivity had decreased in hippocampus and frontal cortex (data not shown).

The number of GFAP-positive cells appeared to increase at several sites within the hippocampus as a consequence of TMTinduced injury. To verify that astrocyte mitosis had occurred, rats were pulsed with ${ }^{3} \mathrm{H}$-thymidine. Maximal incorporation of label was observed $4-5 \mathrm{~d}$ after administration of TMT. Astro-

Table 2. Effects of TMT on p38 and GFAP in regions of dorsal hippocampus

\begin{tabular}{|c|c|c|c|c|c|}
\hline \multirow[b]{3}{*}{ Region $^{a}$} & \multirow{3}{*}{$\begin{array}{l}\text { Treat- } \\
\text { ment }^{b}\end{array}$} & \multicolumn{4}{|c|}{ Relative specific activity ${ }^{c}$} \\
\hline & & \multicolumn{2}{|l|}{ p38 } & \multicolumn{2}{|l|}{ GFAP } \\
\hline & & Total & Concentration & Total & Concentration \\
\hline \multirow[t]{2}{*}{ Fascia dentata } & Saline & $1.00 \pm 0.04$ & $1.00 \pm 0.03$ & $1.00 \pm 0.17$ & $1.00 \pm 0.14$ \\
\hline & TMT & $0.50 \pm 0.03^{* * *}$ & $0.57 \pm 0.03^{* * *}$ & $10.93 \pm 1.40^{*}$ & $12.53 \pm 1.51^{*}$ \\
\hline \multirow[t]{2}{*}{$\mathrm{CAl}$} & Saline & $1.14 \pm 0.02$ & $0.96 \pm 0.05$ & $0.71 \pm 0.28$ & $0.60 \pm 0.23$ \\
\hline & TMT & $0.66 \pm 0.04^{* * *}$ & $0.59 \pm 0.04^{* * *}$ & $10.18 \pm 1.76^{*}$ & $9.29 \pm 1.57^{*}$ \\
\hline \multirow[t]{2}{*}{ CA3 } & Saline & $0.82 \pm 0.03$ & $0.94 \pm 0.04$ & $0.11 \pm 0.05$ & $0.13 \pm 0.06$ \\
\hline & TMT & $0.52 \pm 0.05^{* * *}$ & $0.61 \pm 0.04^{* *}$ & $7.32 \pm 0.95^{* *}$ & $8.70 \pm 0.97^{* *}$ \\
\hline
\end{tabular}

${ }^{a}$ Slices of dorsal hippocampus were subdivided into areas designated fascia dentata, CA1, and CA3, as described (O'Callaghan and Miller, 1984). When dissected in this manner, regions designated CA1 and CA3 would each contain a portion of CA2; subfields CA $3 c$ and $\mathrm{CA} 4$, as well as the molecular and granular layer of the dentate gyrus, would comprise the region designated fascia dentata.

${ }^{b}$ Subjects were killed $21 \mathrm{~d}$ after the administration of saline $(0.9 \%)$ or TMT $(8.0 \mathrm{mg} / \mathrm{kg})$.

' Each value $(n=6)$ represents the mean RSA \pm SEM expressed on a total (per hippocampus) or concentration (per mg protein) basis. Values obtained for fascia dentata-saline were used to calculate a mean RSA $=1.00$; see Materials and Methods for additional details.

* Significantly different from saline, $p<0.005$.

** Significantly different from saline, $p<0.0005$.

*** Significantly different from saline, $p<0.0001$. 

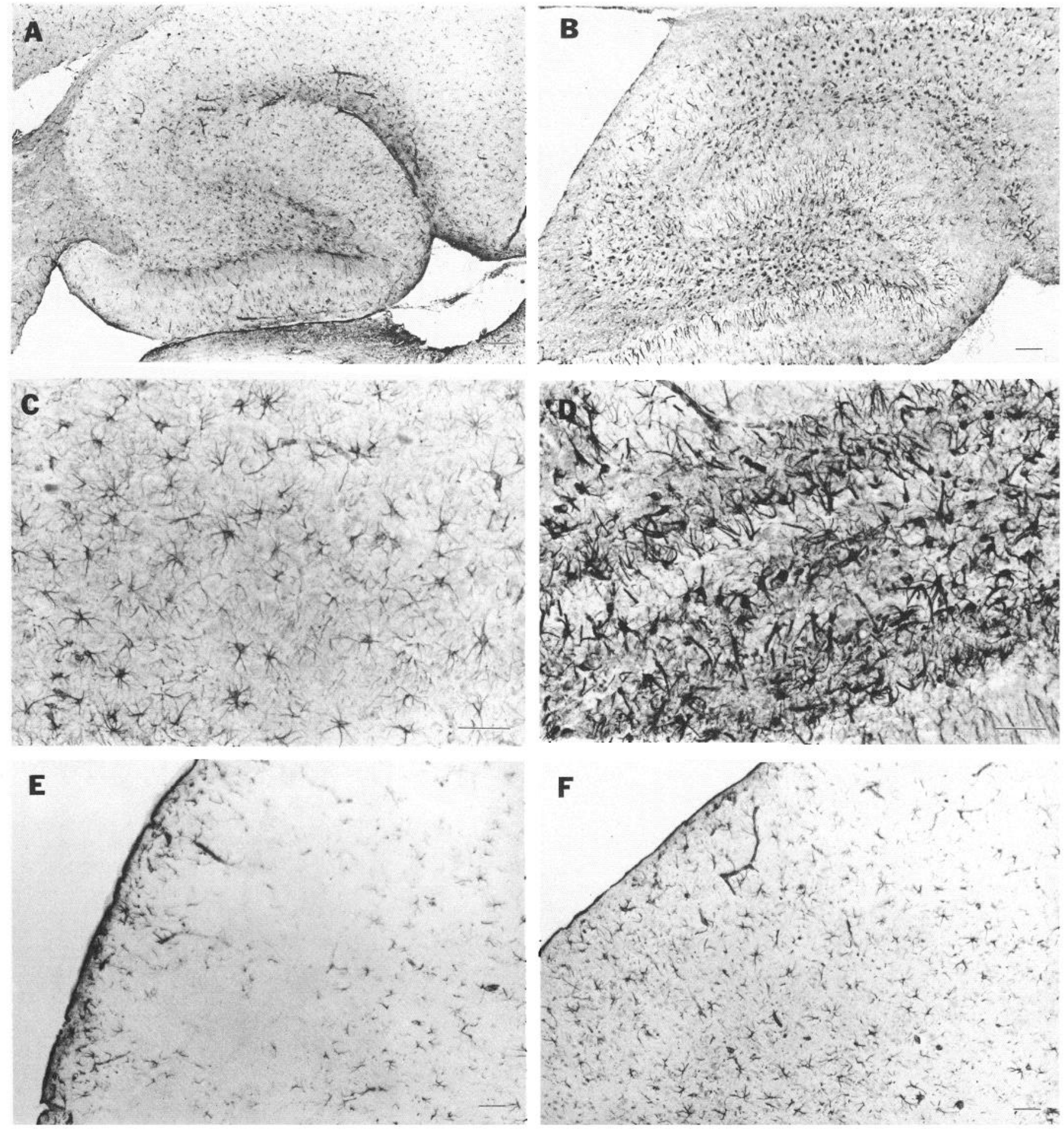

Figure 7. GFAP immunohistochemistry in sagittal sections of hippocampus and frontal cortex. Sections on the right $(B, D, F)$ were obtained 21 $\mathrm{d}$ after acute administration of TMT $(8.0 \mathrm{mg} / \mathrm{kg})$; sections on the left $(A, C, E)$ were obtained from corresponding saline controls. $A, B$, hippocampal formation. Bars, $100 \mu \mathrm{M}$. $C, D$, Astrocytic immunoreactivity approximate to neurons (unstained) in CA3c-CA4. Bars, $50 \mu \mathrm{M}$. $E, F$, Frontal cortex. Bars, $50 \mu \mathrm{M}$.

cyte counts obtained from subfields CA3c-CA4 5 d post-TMT showed an increase in cell number (see legend to Fig. 8), with several GFAP-positive cells showing reduced silver grains over their nuclei. These ${ }^{3} \mathrm{H}$-labeled cells, however, represented less than $1 \%$ of the GFAP-positive cells in the pyramidal cell layer. In several instances, silver grains were localized to nuclei that did not appear to be associated with GFAP-positive cells (e.g., Fig. 8). Tissue obtained from saline controls was devoid of silver grains over GFAP-positive or GFAP-negative cells (data not shown).

Two-dimensional gel electrophoresis. To determine if cell typeassociated proteins, in addition to synapsin I, p38, and GFAP, 
Figure 8. GFAP immunohistochemistry in areas CA3c-CA4 of hippocampus, combined with microautoradiography of ${ }^{3} \mathrm{H}$-thymidine incorporation. The subject was pulsed with ${ }^{3} \mathrm{H}$-thymidine $5 \mathrm{~d}$ after administration of TMT $(8.0 \mathrm{mg} / \mathrm{kg})$. Saline controls did not show incorporation of ${ }^{3} \mathrm{H}$-thymidine; see Materials and Methods for additional details. Large arrow, Silver grains overlying nuclei of GFAP-positive cell. Small arrows, Silver grains not clearly associated with GFAP-positive cells. Mean number of astrocytes (GFAPpositive cells) in CA3c-CA4: saline, $96 \pm 9 ;$ TMT, $150 \pm 21$. Less than $1 \%$ of astrocytes in TMT group showed incorporation of ${ }^{3} \mathrm{H}$-thymidine.

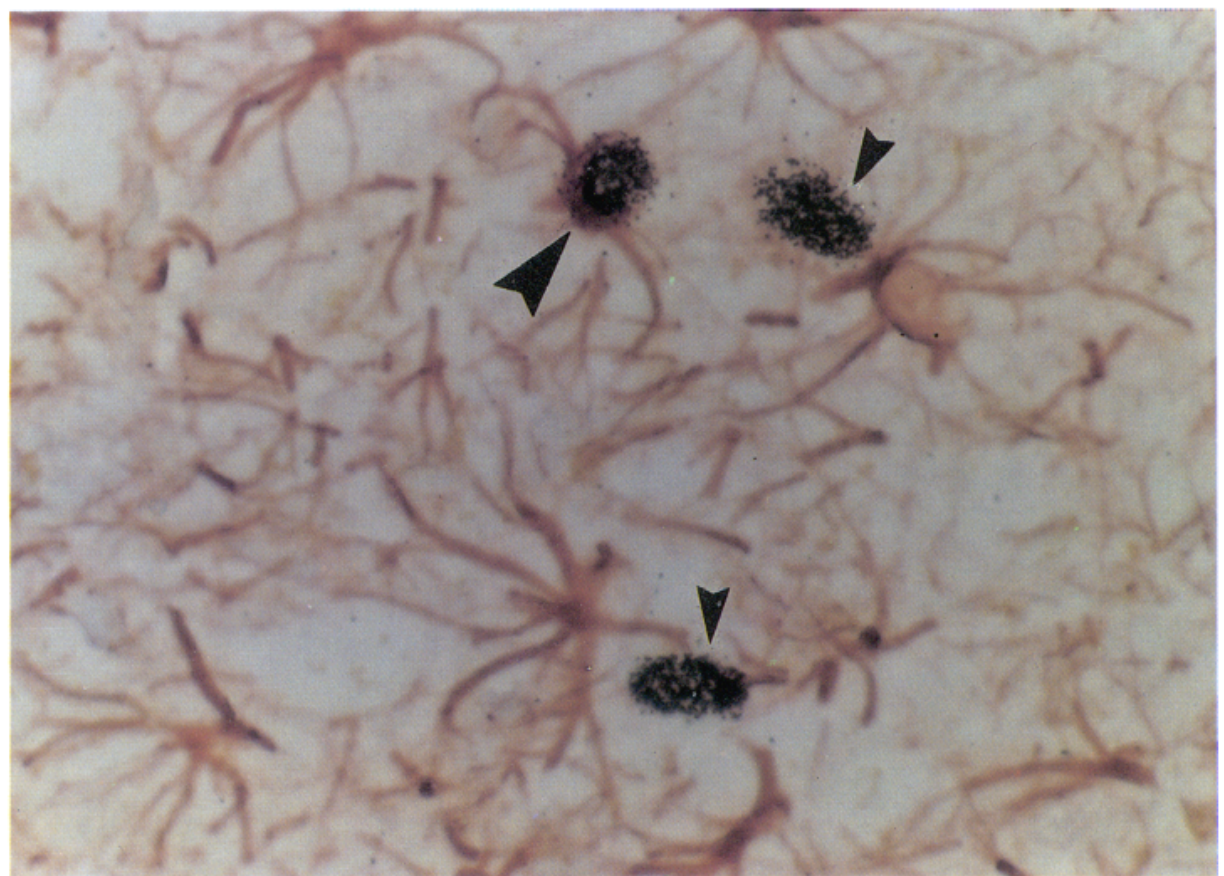

were altered by TMT, we subjected homogenates of hippocampus and frontal cortex to 2-dimensional PAGE. Representative electrophoretic profiles are shown in Figure 9. Proteins relatively low in abundance (e.g., synapsin I and p38) or outside the limits of the pH gradient (e.g., synapsin I) were not detected. Of the total number of hippocampus and frontal cortex proteins resolved, only a small percentage showed qualitative changes in staining intensity as a consequence of the administration of TMT. As was expected from the RIA data, 1 protein that was consistently increased in hippocampus and frontal cortex was identified by immunoblotting as GFAP. Two other proteins, however, were consistently decreased in samples of hippocampus and frontal cortex. One of these was positively identified as the neuronal cytoskeletal protein NF p68 (Hoffman and Lasek,

Table 3. Effects of TMT on gliotypic and neurotypic proteins resolved by 2-dimensional PAGE

\begin{tabular}{llll} 
& & \multicolumn{2}{c}{$\begin{array}{l}\text { Integrated optical density } \\
\text { (\% saline) }\end{array}$} \\
\cline { 3 - 4 } Protein $^{a}$ & Treatment $^{b}$ & Hippocampus & Frontal cortex \\
\hline GFAP & Saline & $100 \pm 12$ & $100 \pm 13$ \\
& TMT & $410 \pm 87^{* *}$ & $461 \pm 142^{*}$ \\
NF 68 & Saline & $100 \pm 12$ & $100 \pm 9$ \\
& TMT & $60 \pm 12^{*}$ & $78 \pm 16$ \\
NSE & Saline & $100 \pm 2$ & $100 \pm 7$ \\
& TMT & $63 \pm 6^{* * *}$ & $77 \pm 12$
\end{tabular}

a GFAP, glial fibrillary acidic protein; NF 68 , neurofilament p68; NSE, neuronspecific enolase.

${ }^{b}$ Subjects were killed $21 \mathrm{~d}$ after the administration of saline $(0.9 \%)$ or TMT $(8.0$ $\mathrm{mg} / \mathrm{kg}$ ).

- Each value $(n=5)$ represents the mean \pm SEM; see Materials and Methods for additional details.

${ }^{*}$ Significantly different from corresponding saline control, $p<0.05$.

** Significantly different from corresponding saline control, $p<0.001$.

*** Significantly different from corresponding saline control, $p<0.0001$.
1975), whereas the other (designated “NSE?") was tentatively identifed as NSE (Pickel et al., 1976; Schmechel et al., 1978) on the basis of its reported electrophoretic profile (Lim et al., 1983; Heydorn et al., 1985). Computer-assisted densitometry revealed that TMT caused a significant reduction in both NF p68 and NSE in hippocampus, as well as the expected increase in GFAP (>4-fold) in hippocampus and frontal cortex (Table 3).

\section{Discussion}

A single administration of TMT to the rat produces consistent regional and cell type-specific damage of the CNS (Brown et al., 1979; Chang and Dyer, 1983; O'Callaghan and Miller, 1984). Our results demonstrate that these cytopathological effects of TMT are accompanied by time- and dose-dependent changes in neurotypic and gliotypic proteins. Together with our previous observations (O'Callaghan and Miller, 1984, 1985, 1986), these data suggest that neurotypic and gliotypic proteins can be used to characterize the temporal and regional patterns of neuronal and glial responses to CNS damage.

In agreement with our previous findings (O'Callaghan and Miller, 1984), TMT-induced damage of the hippocampus was manifested morphologically by decrements in wet weight and loss of pyramidal cells. On a per hippocampus (total) basis, these effects were accompanied by a permanent decrease in the synaptic vesicle-associated proteins synapsin I and p38. This reduction in total synapsin I and p38 did not reflect a generalized decrease coincident with the loss of tissue, because the percentage decrease in these proteins was always greater than the percentage decrease in hippocampal weight. This observation indicates that a preferential loss of these proteins occurs as a direct or indirect consequence of TMT-induced damage to the hippocampus. Furthermore, because synapsin I and p38 are present in all nerve terminals (De Camilli et al., 1983a, b; Navone et al., 1986), a reduction in the absolute amount of these proteins (total) is suggestive of a loss of synapses due to damage 


\section{HIPPOCAMPUS}

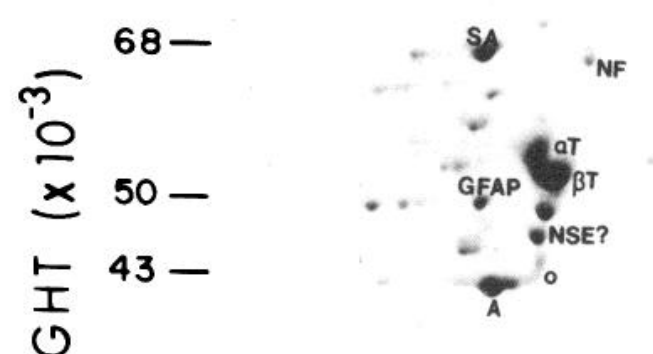

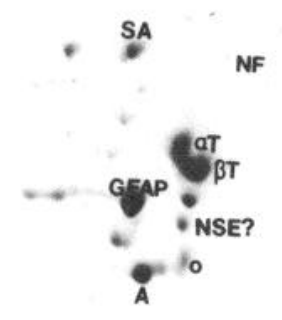

\section{FRONTAL CORTEX}

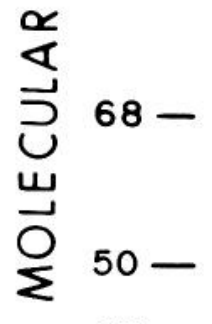

$43-$

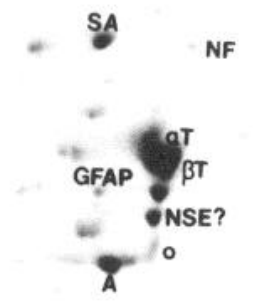

SALINE

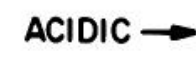

$A C I D I C \rightarrow$

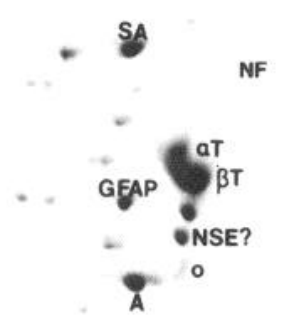

TMT
Figure 9. Effects of TMT on proteins resolved from $1.0 \%$ SDS homogenates of hippocampus and frontal cortex. Subjects were killed $21 \mathrm{~d}$ after treatment with saline $(0.9 \%)$ or TMT $(8.0$ $\mathrm{mg} / \mathrm{kg}$ ). Proteins were stained with Coomassie blue R250. See Materials and Methods for details concerning the identification of individual proteins. $G F A P$, glial fibrillary acidic protein; $N F$, neurofilament p68; NSE?, neuron-specific enolase?; $S A$, serum albumin; $\alpha T$, $\alpha$-tubulin; $\beta T, \beta$-tubulin; $A$, actin; and $\circ$, ovalbumin (internal standard). to intrinsic or afferent neurons of the hippocampal formation. The possibility does exist, however, that a decrease in either the number of synaptic vesicles per synapse or in the amount of synapsin I and p38 per vesicle could account for our findings (see Goelz et al., 1981).

The concentration of synapsin I and p38 in hippocampus was also reduced in a dose- and time-dependent fashion following the administration of TMT. Unlike alterations in total synapsin I and p38, which reflect absolute changes, alterations in the concentration of these proteins, in theory, may result from increases in the content of other proteins, especially relatively abundant ones (e.g., $\alpha$ - and $\beta$-tubulin, GFAP). Alternatively, changes in the concentration of synapsin I and p38 may reflect specific protein alterations that accompany injury to the hippocampus - an interpretation we favor because of the following observations. First, quantitative analysis of specific protein concentration by 1- (O'Callaghan and Miller, 1984) and 2-dimensional PAGE, as well as by specific RIAs not reported here (e.g., $\alpha$ - and $\beta$-tubulin; J. P. O'Callaghan, unpublished observations), failed to reveal changes in most proteins as a consequence of exposure to TMT, a finding that suggests that the changes in specific protein concentrations (synapsin I, p38, GFAP, NF 68, and neuron-specific enolase, NSE) did not result from changes in the relative abundance of other hippocampal proteins. Second, consistent with our findings, alterations in the concentration of specific brain proteins relevant to disease- (Marotta et al., 1981; Selkoe et al., 1982), trauma- (Soifer et al., 1981; Perry et al., 1985), or stress- (Greenberg and Lasek, 1985) induced events occurred independently of changes in other tissue proteins. Finally, changes in the concentration of GFAP in frontal cortex were not associated with a concomitant decrease in synapsin $I$ and $p 38$, which suggests that changes in the specific concentration of a protein high in relative abundance (GFAP) do not necessarily alter the concentrations of proteins low in relative abundance (e.g., synapsin I and p38).

On the basis of our data, we cannot localize the loss of synapsin I and $\mathrm{p} 38$ to a specific population of hippocampal neurons. However, two lines of evidence support the hypothesis that the reduced amounts of these proteins result primarily from the loss of pyramidal cells. First, there was a close correspondence between the time course of pyramidal cell loss and that of the loss of synapsin I and p38. Second, the greatest number of synapses in hippocampal tissue occur between axon collaterals of pyramidal cells and dendrites of other pyramidal cells (Braitenberg and Schüz, 1983); therefore, the degree $(75 \%$ decrease) and extent (CA1-CA4) of pyramidal cell loss caused by TMT would be expected to result in a considerable loss of synapses and synapse-localized proteins. The degree $(60-70 \%)$ and extent (CA1-CA4) of the decrease in synapsin I and p38 are consistent with these expectations. It is likely that a more detailed understanding of the cellular targets associated with hippocampal damage due to TMT or other injury-inducing paradigms may be achieved through the use of monoclonal antibodies that preferentially label specific cellular and subcellular elements of the hippocampal formation. Such antibodies have recently been described (Caceres et al., 1984; De Camilli et al., 1984; Levitt, 1984; Moskal and Schaffner, 1986).

An increase in the amount of synapsin I and p38 per hippocampus and an increase in the concentration of these proteins in hippocampus were observed between 5 and 12 weeks after 
administration of TMT. One explanation that may account for these increases is that synaptic growth was evoked by partial denervation of the hippocampus (Cotman and Nadler, 1978; Cotman et al., 1981; Cotman and Nieto-Sampedro, 1984). The following lines of evidence are consistent with this interpretation. (1) Synaptic replacement following injury to the CNS is especially prevalent in the hippocampus (Cotman and Nadler, 1978; Cotman et al., 1981; Tsukahara, 1981). (2) The return of synapsin I values toward control levels occurs more rapidly in the neonate (Miller and O'Callaghan, 1984) than in the adult. Both these findings are in agreement with the observation that synaptic replacement occurs more readily in the immature animal than in the adult (Gall and Lynch, 1980; Tsukahara, 1981; McWilliams and Lynch, 1983). Finally, (3) destruction of hippocampal pyramidal cells with kainic acid results first in the loss of hippocampal synapses and then in their replacement 68 weeks later (Nadler et al., 1980), findings consistent with those for TMT. Although an increased synthesis of synapsin I and p38 associated with synaptic ingrowth offers an attractive explanation for the observed data, alterations in degradation or transport of these proteins represent alternative hypotheses equally worthy of further investigation.

Glial fibrillary acidic protein is the major protein of intermediate filaments in astrocytes (Eng, 1985) and, as such, has been proposed as a marker for assessing astrocytic response to injury (for revicws, scc Dc Armond et al., 1980; Eng and De Armond, 1981; O'Callaghan and Miller, 1983; Eng, 1987). The striking increments in GFAP content (total and concentration) and the increased immunostaining of astrocytes that accompanies TMT-induced injury, together with our data showing the effects of other toxic insults on GFAP (O'Callaghan and Miller, 1985, 1986), support the hypothesis that increases in GFAP reflect astrocytic response to injury. Although the findings of the present study suggest that neuronal damage initiates the astroglial reaction, the possibility that astrocytes are directly affected by TMT cannot be ruled out.

A feature of the GFAP response to TMT that set it apart from the changes observed for synapsin I and p38 was its presence in frontal cortex. One interpretation of these data is that increased frontal cortex GFAP represented the spread of astrocytic reactivity from the primary site of damage, the hippocampus (c.g., sec Mathewson and Berry, 1985); alternatively, this increase may have reflected astrocytic response to TMT-induced damage to the frontal cortex itself. We feel that the latter explanation is the more plausible for several reasons. First, the decrease in p38 $(9.0 \mathrm{mg} / \mathrm{kg})$ suggested neuronal damage in frontal cortex due to TMT. Second, the temporal increases of GFAP in hippocampus and frontal cortex were strikingly similar, which does not support the idea of a spread of astrocytic reactivity from a hippocampal focus. Finally, the temporal increase in GFAP immunostaining due to TMT was similar in hippocampus and frontal cortex, and the spread of reactivity in each region did not extend to surrounding structures.

Astrocytic reactivity following a single stab wound to the CNS declines with time to the pretraumatic resting state (Lagenaur et al., 1982; Mathewson and Berry, 1985). The increased amounts of GFAP due to TMT also declined with time to nearly control values, indicating that acute chemical or physical lesions may elicit a similar astrocytic response to injury. The transient nature of the GFAP response to TMT- or stab-inflicted damage stands in contrast to our observation of an apparently permanent increase in GFAP in the cerebellum of the Gunn rat, an autosomal recessive mutant characterized by life-long loss of cerebellar Purkinje cells (see O'Callaghan and Miller, 1985). What distinguishes damage in the Gunn rat from that due to TMT or stabbing is that neuronal loss in the former is a continuing event throughout its life, while cell loss in the latter occurs as a single, relatively short-lived episode. These findings raise the possibility that continuing CNS damage is necessary to maintain an astrocytic (GFAP) response. Related to this hypothesis are the recent observations of Nieto-Sampedro et al. (1985) demonstrating a transient production of astrocyte mitogenic and morphogenic factors in response to a single cortical lesion. If these factors regulate the astrocytic response to injury, then we predict they will remain elevated in CNS tissue from chronically injured subjects such as the Gunn rat or neurologically mutant mice (e.g., Sommer and Schachner, 1981).

Changes in astrocytic size and appearance are widely accepted responses to CNS trauma, but hyperplasia has been difficult to document because of uncertainties associated with identifying the dividing cells or the lineage of precursor cells (Cavanagh, 1970; Skoff and Vaughn, 1971; Skoff, 1980; Nathaniel and Nathaniel, 1981). These obstacles notwithstanding, the results of several investigations indicate that astrocytic proliferation occurs in response to CNS trauma. For example, Latov and coworkers (1979) have demonstrated that a small portion of reactive astrocytes (1-2\% of GFAP-positive cells) in frontal cortex incorporate ${ }^{3} \mathrm{I} I$-thymidine after mechanical damage to this area. Consistent with these observations are reports (Billingsley and Mandel, 1982; Politis and Houle, 1985) showing that inhibitors of DNA synthesis decrease the incorporation of ${ }^{3} \mathrm{H}$-thymidine into cortical DNA and inhibit the proliferation of glial cells following cortical trauma. Our data indicate that the effects of TMT and perhaps other chemical toxicants (e.g., see O'Callaghan and Miller, 1985, 1986), like trauma-induced damage of the CNS, may also promote the division of astrocytes (GFAPpositive cells) and possibly other glial cells (e.g., oligodendroglia; see Arenella and Herndon, 1984; Ludwin, 1984).

On the basis of evidence obtained from specific RIAs, immunohistochemistry, and 2-dimensional PAGE, we have shown that cell type-specific responses to CNS injury can be characterized by measuring neurotypic and gliotypic proteins. The sensitivity, specificity, and quantitative nature of this approach should prove uscful for charactcrizing specific responses to injury (e.g., reactive synaptogenesis, astrocytic reactivity, or specific neurological disease states), as well as for assessing the effects of putative neuronotropic or gliotropic factors on the damaged or intact CNS.

\section{References}

Arenella, L. S., and R. M. Herndon (1984) Mature oligodendrocytes: Division following experimental demyelination in adult animals. Arch. Neurol. 41: 1162-1165.

Barrett, C. P., E. J. Donati, and L. Guth (1984) Differences between adult and neonatal rats in their astroglial response to spinal injury. Exp. Neurol. 84: 374-385.

Bignami, A., and D. Dahl (1976) The astroglial response to stabbing. Immunofluorescent studies with antibodies to astrocyte-specific protein (GFA) in mammalian and submammalian vertebrates. Neuropathol. Appl. Neurobiol. 2: 99-111.

Bignami, A., L. F. Eng, D. Dahl, and T. Uyeda (1972) Localization of the glial fibrillary acidic protein in astrocytes by immunofluorescence. Brain Res. 43: 429-435.

Bignami, A., D. Dahl, and C. D. Reuger (1980) Glial fibrillary acidic protein (GFA) in normal neural cells and in pathologic conditions. In Advances in Cellular Neurobiology, vol. 1, S. Federoff and L. Hertz, eds., pp. 285-310, Academic, New York. 
Billingsley, M. L., and H. G. Mandel (1982) Effects of DNA synthesis inhibitors on post-traumatic glial cell proliferation. J. Pharmacol. Exp. Ther. 222: 765-770.

Billingsley, M. L., J. A. Straw, and H. G. Mandel (1982) Glial DNA synthesis and cell proliferation in the lesioned frontal cortex of the rat. Brain Res. 247: 325-334.

Bouldin, T. W., N. D. Goines, C. R. Bagnall, and M. R. Krigman (1981) Pathogenesis of trimethyltin toxicity. Ultrastructural and cytochemical observations. Am. J. Pathol. 104: 237-249.

Braitenberg, V., and A. Schüz (1983) Some anatomical comments on the hippocampus. In Neurobiology of the Hippocampus, W. Seifert, ed., pp. 21-37, Academic, New York.

Brock, T. O., and D. L. Mcllwain (1985) Relative postmortem stability of spinal motoneural proteins detectable by two-dimensional electrophoresis. Neurochem. Pathol. 3: 1-14.

Brown, A. W., W. M. Aldridge, B. W. Street, and R. D. Verschoyle (1979) The behavioral and neuropathological sequelae of intoxication by trimethyltin compounds in the rat. Am. J. Pathol. 97: 59-82.

Burnette, W. N. (1981) "Western blotting." Electrophoretic transfer of proteins from sodium dodecyl sulfate-polyacrylamide gels to unmodified nitrocellulose and radiographic detection with anatibody and radioiodinated protein A. Anal. Biochem. 112: 195-203.

Caceres, A., L. I. Binder, M. R. Payne, P. Bender, L. Rebhun, and O. Steward (1984) Differential subcellular localization of tubulin and the microtubule-associated protein MAP2 in brain tissue as revealed by immunocytochemistry with monoclonal hybridoma antibodies. $\mathrm{J}$. Neurosci. 4: 394-410.

Cavanagh, J. B. (1970) The proliferation of astrocytes around a needle wound in the rat brain. J. Anat. 106: 471-487.

Chang, L. W., and R. S. Dyer (1983) A time course study of trimethyltin-induced neuropathology in rats. Neurobehav. Toxicol. Teratol. 5: 443-459.

Cotman, C. W., and J. V. Nadler (1978) Reactive synaptogenesis in the hippocampus. In Neuronal Plasticity, C. W. Cotman, ed., pp. $227-$ 231, Raven, New York.

Cotman, C. W., and M. Nieto-Sampedro (1984) Cell biology of synaptic plasticity. Science 225: 1287-1294.

Cotman, C. W., M. Nieto-Sampedro, and E. W. Harris (1981) Synapse replacement in the nervous system of adult vertebrates. Physiol. Rev. 61: 684-784.

Danscher, G., E. J. Fjerdingstad, and K. Fredens (1976) Heavy metal content in subdivisions of the rat hippocampus (zinc, lead and copper). Brain Res. 112: 442-446.

De Armond, S. J., L. F. Eng, and L. J. Rubenstein (1980) The application of glial fibrillary acidic (GFA) protein immunohistochemistry in neurooncology: A progress report. Pathol. Res. Pract. 168: 374394.

De Blas, A. L., R. O. Kuljis, and H. M. Cherwinski (1984) Mammalian brain antigens defined by monoclonal antibodies. Brian Res. 322: 277-287.

De Camilli, P., R. Cameron, and P. Greengard (1983a) Synapsin I (protein I), a nerve terminal-specific phosphoprotein I. Its general distribution in synapses of the central and peripheral nervous system demonstrated by immunofluorescence in frozen and plastic sections. J. Cell Biol. 96: 1337-1354.

De Camilli, P., S. M. Harris, W. B. Huttner, and P. Greengard (1983b) Synapsin I (protein I), a nerve terminal-specific phosphoprotein II. Its specific association with synaptic vesicles demonstrated by immunocytochemistry in agarose embedded synaptosomes. J. Cell Biol. 96: 1355-1379.

De Camilli, P., P. E. Miller, F. Navone, W. E. Theurkauf, and R. B. Vallee (1984) Distribution of microtubule-associated protein 2 in the nervous system of the rat studied by immunofluorescence. Neuroscience $11: 819-846$.

Eng, L. F. (1980) The glial fibrillary acidic (GFA) protein. In Proteins of the Nervous System, R. A. Bradshaw and D. M. Schneider, eds., pp. 85-117, Raven, New York.

Eng, L. F. (1985) Glial fibrillary acidic protein (GFAP): The major protein of glial intermediate filaments in differentiated astrocytes. $\mathrm{J}$. Neuroimmunol. 8: 203-214.

Eng, L. F. (1987) Experimental models for astrocyte activation and fibrous gliosis. In Glial-Neuronal Communication in Development and Regeneration, H. H. Althaus and W. Seifert, eds., Springer-Verlag, Heidelberg (in press).

Eng, L. F., and S. J. De Armond (1981) Glial fibrillary acidic (GFA) protein immunocytochemistry in development and neuropathology. In Eleventh International Congress of Anatomy: Glial and Neuronal Cell Biology, pp. 65-79, Alan R. Liss, New York.

Eng, L. F., and S. J. De Armond (1982) Immunocytochemical study of astrocytes in normal development and disease. In Advances in Cellular Neurobiology, vol. 3, S. Federoff and L. Hertz, eds., pp. 145171, Academic, New York.

Gall, C., and G. Lynch (1980) Fiber architecture of the dentate gyrus following ablation of the entorhinal cortex in rats of different ages: Evidence for two forms of axon sprouting in the immature brain. Neuroscience 6: 903-910.

Goelz, S. E., E. J. Nestler, B. Cherazi, and P. Greengard (1981) Distribution of protein I in mammalian brain as determined by a detergent-based radioimmunoassay. Proc. Natl. Acad. Sci. USA 78: 2130 2134.

Greenberg, S. G., and R. J. Lasek (1985) Comparison of labeled heat shock proteins in neuronal and non-neuronal cells of Aplysia californica. J. Neurosci, 5: 1239-1245.

Heydorn, W. E., J. G. Creed, P. J. Marangos, and D. M. Jacobowitz (1985) Identification of neuron-specific enolase and non-neuronal enolase in human and rat brain on two-dimensional gels. J. Neurochem. 44: 201-210.

Hoffman, P. N., and R. J. Lasek (1975) The slow component of axonal transport. Identification of major structural polypeptides of the axon and their generality among mammalian neurons. J. Cell Biol. 66: 351-366.

Huttner, W. B., W. Schicbler, P. Greengard, and P. De Camilli (1983) Synapsin I (protein I), a nerve terminal-specific phosphoprotein III. Its association with synaptic vesicles studied in a highly purified synaptic vesicle preparation. J. Cell Biol. 96: 1374-1388.

Jahn, R., W. Schiebler, and P. Greengard (1984) A quantitative dot immunobinding assay for proteins using nitrocellulose membrane filters. Proc. Natl. Acad. Sci. USA 81:1684-1687.

Jahn, R., W. Schiebler, C. Ouimet, and P. Greengard (1985) A 38,000 dalton protein (p-38) present in synaptic vesicles. Proc. Natl. Acad. Sci. USA 82: 4137-4141.

Kopriwa, B., and C. Leblond (1962) Improvements in the coating technique for radioautography. J. Histochem. Cytochem. 10: 269284.

Lagenaur, C., C. Masters, and M. Schachner (1982) Changes in expression of glial antigens $\mathrm{Ml}$ and $\mathrm{Cl}$ after cerebellar injury. J. Neurosci. 2: $470-476$.

Latov, N., G. Nilaver, E. A. Zimmerman, W. G. Johnson, A. Silverman, R. Defendindi, and L. Cote (1979) Fibrillary astrocytes proliferate in response to brain injury. Dev. Biol. 72: 381-384.

Levitt, P. (1984) A monoclonal antibody to limbic system neurons. Science 223: 299-301.

Lim, L., C. Hall, T. Leung, L. Mashaderan, and S. Whatley (1983) Neuron-specific enolase and creatine phosphokinase are components of the rat brain synaptic plasma membrane. J. Neurochem. 41: $1177-$ 1182.

Lorente de Nó, R. (1934) Studies on the structure of the cerebral cortex. II. Continuation of the study of the ammonic system. J. Psychol. Neurol. 46: 113-177.

Lowry, O., N. J. Rosebrough, A. L. Farr, and R. J. Randall (1951) Protein measurement with the Folin phenol reagent. J. Biol. Chem. 193: 265-275.

Ludwin, S. K. (1984) Proliferation of mature ologodendrocytes after trauma to the central nervous system. Nature 308: 274-275.

Marotta, C. A., P. Srocchi, B. A. Brown, J. A. Bonventre, and J. M. Gilbert (1981) Gel electrophoresis methods for the characterization of neuronal fibrous proteins: Application to studies of human brain macromolecules from postmortem tissue. In Genetic Research Strategies for Psychobiology and Psychiatry, E. S. Gershon, S. Matthysse, and X. O. Brakefield, eds., pp. 39-57, Boxwood Press, Pacific Grove, CA.

Mathewson, A. J., and M. Berry (1985) Observations on the astrocyte response to a cerebral stab wound in adult rats. Brain Res. $327: 61$ 69.

McWilliams, R. R., and G. Lynch (1983) Ratc of synaptic replaccment in denervated rat hippocampus declines precipitously from the juvenile period to adulthood. Science 221: 572-574.

Miller, D. B., and J. P. O'Callaghan (1984) Biochemical, functional and morphological indicators of neurotoxicity. Effects of acute admin- 
istration of trimethyltin to the developing rat. J. Pharmacol. Exp. Ther. 231: 744-751.

Milner, R. J., and J. G. Sutcliffe (1983) Gene expression in rat brain. Nucleic Acids Res. 11: 5497-5520.

Moskal, J. R., and A. E. Schaffner (1986) Monoclonal antibodies to the dentate gyrus: Immunocytochemical characterization and flow cytometric analysis of hippocampal neurons bearing a unique cellsurface antigen. J. Neurosci. 6: 2045-2053.

Nadler, J. V., B. W. Perry, C. Gentry, and C. W. Cotman (1980) Loss and reacquisition of hippocampal synapses after selective destruction of CA3-CA4 afferents with kainic acid. Brain Res. 191: 387-403.

Nairn, A. C., J. A. Detre, J. E. Casnelli, and P. Greengard (1982) Serum antibodies that distinguish between the phospho- and dephosphoforms of a phosphoprotein. Nature 299: 734-736.

Nathaniel, E. J. H., and D. R. Nathaniel (1981) The reactive astrocyte. In Advances in Cellular Neurobiology, vol. 2, S. Federoff and L. Hertz, eds., pp. 249-301, Academic, New York.

Navone, F., P. Greengard, and P. De Camilli (1984) Synapsin I in nerve terminals: Selective association with small synaptic vesicles. Science 226: 1209-1211.

Navone, F., R. Jahn, P. Greengard, and P. De Camilli (1986) Protein p38, like synapsin $I$, is present in all nerve terminals and is selectively associated with small synaptic vesicles. J. Cell Biol. 103: 2511-2527.

Nestler, E. J., and P. Greengard (1984) Protein Phosphorylation in the Nervous System, Wiley, New York.

Nestler, E. J., S. I. Walaas, and P. Greengard (1984) Neuronal phosphoproteins: Physiological and clinical implications. Science 225: 1357-1364.

Nieto-Sampedro, M., R. P. Saneto, J. de Vellis, and C. W. Cotman (1985) The control of glial populations in brain: Changes in astrocyte mitogenic and morphogenic factors in response to injury. Brain Res. 343: 320-328.

O'Callaghan, J. P., and D. B. Miller (1983) Nervous system-specific proteins as biochemical indicators of neurotoxicity. Trends Pharmacol. Sci. 4: 388-390.

O'Callaghan, J. P., and D. B. Miller (1984) Neuron-specific proteins as biochemical indicators of neurotoxicity. Effects of acute administration of trimethyltin to the adult rat. J. Pharmacol. Exp. Ther. 231: 736-743.

O'Callaghan, J. P., and D. B. Miller (1985) Cerebellar hypoplasia in the Gunn rat is associated with quantitative changes in neurotypic and gliotypic proteins. J. Pharmacol. Exp. Ther. 234: 522-533.

O'Callaghan, J. P., and D. B. Miller (1986) Diethyldithiocarbamate increases cadmium distribution to brain but prevents cadmium-induced neurotoxicity. Brain Res. 370: 354-358.

O'Callaghan, J. P., D. B. Miller, and L. W. Reiter (1983) Acute postnatal exposure to triethyltin in the rat. Effects on specific protein composition of subcellular fractions from developing and adult rat brain. J. Pharmacol. Exp. Ther. 224: 466-472.

O'Farrell, P. H. (1975) High resolution two-dimensional electrophoresis of proteins. J. Biol. Chem. 250: 4007-4021.

Paxinos, G., and C. Watson (1982) The Rat Brain in Stereotaxic Coordinates, Academic, New York.

Perry, G. W., D. W. Burmeister, and B. Grafstein (1985) Changes in protein content of goldfish optic nerve during degeneration and regeneration following nerve crush. J. Neurochem. 44: 1142-1151.

Pickel, V. M., D. J. Reis, P. J. Marangos, and C. Zomzely-Ncurath (1976) Immunocytochemical localization of nervous system specific protein (NSP-R) in rat brain. Brain Res. 105: 184-187.

Politis, M. J., and J. D. Houle (1985) Effect of cytosine arabinofuranoside (Ara C) on reactive gliosis in vivo. An immunohistochemical and morphometric study. Brain Res. 328: 291-300.
Price, D. L., and J. W. Griffin (1980) Neurons and ensheathing cells as targets of disease. In Experimental and Clinical Neurotoxicology, P. S. Spencer and H. H. Schaumberg, eds., pp. 2-23, Williams \& Wilkins, Baltimore and London.

Raff, M. C., K. L. Fields, S. Hakomori, R. M., Pruss, and J. Winter (1979) Cell-type-specific markers for distinguishing and studying neurons and the major classes of glial cells in culture. Brain Kes. 174: 283-308.

SAS Institute (1982) SAS User's Guide: Statistics, 1982 Ed., SAS Institute, Cary, NC.

Satterthwaite, F. W. (1946) An approximate distribution of estimates of variance components. Biometrics Bull. 2: 110-114.

Schachner, M. (1982) Cell-type specific surface antigens in the mammalian nervous system. J. Neurochem. 39: 1-8.

Schmechel, D. E., P. J. Marangos, A. P. Zis, M. Brightman, and F. K. Goodwin (1978) The brain enolases as specific markers of neuronal and glial cells. Science 199: 313-315.

Selkoe, D. J., F. J. Salazar, C. Abraham, and K. S. Kosik (1982) Huntington's disease: Changes in striatal proteins reflect astrocytic gliosis. Brain Res. 245: 117-125.

Sinicropi, D. V., and D. L. McIlwain (1983) Changes in the amounts of cytoskeletal proteins within the perikarya and axons of regenerating frog motoneurons. J. Cell Biol. 96: 240-247.

Skoff, R. P. (1980) Neuroglia: A reevaluation of their origin and development. Pathol. Res. Pract. 168: 279-300.

Skoff, R. P., and J. E. Vaughn (1971) An autoradiographic study of cellular proliferation in degenerating rat optic nerve. J. Comp. Neurol. 141: 133-158.

Soifer, D., K. Iqbal, H. Czosnck, J. De Martini, J. A. Sturman, and H. M. Wisniewski (1981) The loss of neuron-specific proteins during the course of Wallerian degeneration of optic and sciatic nerve. $J$. Neurosci. 1: 461-470.

Sommer, I., and M. Schachner (1981) Expression of glial antigens C1 and $\mathrm{M} 1$ in developing and adult neurologically mutant mice. J. Supramol. Struct. 16: 53-74.

Spencer, P. S., and H. H. Schaumberg (1980) Classification of neurotoxic disease. In Experimental and Clinical Neurotoxicology, P. S. Spencer and H. H. Schaumberg, eds., pp. 92-99, Williams \& Wilkins, Baltimore and London.

Sternberger, L. A., P. H. Hardy, J. J. Cuculis, and H. G. Mayer (1970) The unlabeled enzyme antibody method of immunohistochemistry: Preparation and properties of soluble antigen-antibody complex (horseradish peroxidasc-antihorscradish pcroxidase) and its use in identification of spirochetes. J. Histochem. Cytochem. 18: 315-333.

Telewski, F. W., A. H. Wakefield, and M. J. Jaffe (1983) Computerassisted image analysis of tissues of ethral-treated Pinus taeda seedlings. Plant Physiol. 72: 177-181.

Towbin, H., T. Staehelin, and J. Gordon (1979) Electrophoretic transfer of proteins from polyacrylamide gels to nitrocellulose sheets. Procedures and some applications. Proc. Natl. Acad. Sci. USA 76: 43504354.

Tsukahara, N. (1981) Synaptic plasticity in the mammalian central nervous system. Annu. Rev. Neurosci. 4: 351-379.

Viana, M. E., T. O. Brock, and J. P. O'Callaghan (1985) Quantification of the synaptic vesicle proteins, synapsin I and p38, and the astrocytespecific protein, glial fibrillary acidic protein, following trimethyltininduced injury to the rat central nervous system. Soc. Neurosci. Abstr. 11: 419.

Wiedenmann, B., and W. W. Franke (1985) Identification and localization of synaptophysin, an integral membrane glycoprotein of $M$ 38,000 characteristic of presynaptic vesicles. Cell 41: 1017-1028. 